\title{
Beden Eğitiminde Psikolojik İyi Oluşun Bağlamsal Temelleri*
}

\section{Contextual Antecedents of Psychological Well-Being in Physical Education}

\author{
Aykan KURUCAN ${ }^{1}$ \\ Gökçe Erturan İLKER ${ }^{2}$ \\ • Geliş Tarihi: 02.02.2018 • Kabul Tarihi: 19.06.2018 • Yayın Tarihi: 01.01.2019
}

\section{$\ddot{O} z$}

$\mathrm{Bu}$ çalışmanın amacı beden eğitimi derslerinde psikolojik iyi oluşun göstergeleri olan olumsuz değerlendirilme korkusu, konsantrasyon, sosyal görünüş kaygısı ve zindeliğin, öğretmen tarafından sağlanan özerklik desteği, temel psikolojik ihtiyaçların tatmini ve derse ilişkin içsel motivasyon tarafından ne kadar açıklandığını incelemektir. Veriler, iki ayrı devlet okulunda öğrenim gören toplam 431 (\%52 kız, \%48 erkek) lise öğrencisinden toplanmıştır. Ölçek paketi, algılanan özerklik desteği, temel psikolojik ihtiyaçların tatmini, içsel motivasyon, öznel zindelik, konsantrasyon, olumsuz değerlendirilme korkusu ve sosyal görünüş kaygısını ölçen ölçeklerden oluşmaktadır. Yol analizi sonuçları, derste öğretmenin yarattığı özerklik desteğinin, öğrencilerin üç temel psikolojik ihtiyacını açıkladığı, içsel motivasyonunu desteklediği ve bu ilişkinin de öğrencilerin olumsuz değerlendirilme korkusu ve sosyal görünüş kaygısını negatif yönde, öznel zindelik ve konsantrasyon düzeylerini ise pozitif yönde açıkladığını göstermektedir. Sonuçlar 1şığında beden eğitimi derslerinde özerklik desteği, ergenlik dönemindeki öğrencilerin konsantrasyonunu ve zindeliğini artıran, olumsuz değerlendirilme korkusunu azaltan bir araç olarak düşünülebilir. Anahtar sözcükler: özerklik desteği, motivasyon, temel psikolojik ihtiyaçlar, psikolojik iyi oluş, beden eğitimi

\begin{abstract}
The aim of the study was to examine contextual antecedents of psychological well-being in physical education classes. Data were collected from 431 high school students in two public high schools. Questionnaire pack consisted of the scales tapping students' perception of teacher's autonomy support, basic psychological needs satisfaction, intrinsic motivation, fear of negative evaluation, social appearance anxiety, subjective vitality and concentration. Path analysis supported a model in which autonomy support positively predicted students' psychological need satisfaction, which, in turn positively influenced students' intrinsic motivation. Intrinsic motivation positively predicted concentration and subjective vitality positively, fear of negative evaluation negatively. Bearing in mind that teacher's autonomy support in physical education can be considered as a tool to enhance adolescents' concentration and vitality while it can help to reduced adolescents' fear of negative evaluation and social appearance anxiety.
\end{abstract}

Keywords: autonomy support, motivation, basic psychological needs, psychological well-being, physical education

\section{Önerilen Atıf Bilgisi:}

Kurucan, A. ve İlker, G.E. (2019). Beden eğitiminde psikolojik iyi oluşun bağlamsal temelleri. Pamukkale Üniversitesi Ĕ̈itim Fakültesi Dergisi, 45, 23-37.

\footnotetext{
* Bu çalışma, Pamukkale Üniversitesi Bilimsel Araştırma Projeleri Koordinasyon Birimi tarafindan desteklenmiştir. Proje No: 2016-HZDP-026

${ }^{1}$ Doç. Dr., Pamukkale Üniversitesi, Spor Bilimleri Fakültesi, ORCID: 0000-0002-1461-2679, agerturan@pau.edu.tr,

2 Yüksek lisans öğrencisi, Marmara Üniversitesi, Eğitim Bilimleri Enstitüsü, ORCID: 0000-0001-8426-7711 aykankurucan@hotmail.com
} 


\section{Giriş}

Bireylerin beden eğitimi derslerine katılımlarını inceleyen çalışmalar beden eğitimi derslerine severek katılmak ile yaşam boyu fiziksel aktivite alışkanlığı arasında pozitif bir ilişki ortaya koymuşlardır (Hagger, Chatzisarantis, Culverhouse ve Biddle, 2003). Beden eğitimi derslerinin ileriki yaşamda düzenli fiziksel aktivite alışkanlığı kazandırma aracılığı ile toplumların sağlığını etkilediği bilindiğinden, derse olan motivasyonu artırmak önem kazanmıştır. Deci ve Ryan'ın (2000) Özerk Benlik Kuramı, motivasyonun farklı çeşitleri olduğunu ve bu çeşitliliğin motivasyonsuzluktan içsel motivasyona doğru giden bir süreklilik içinde olduğunu ortaya koymaktadır. Kuram, motivasyonun en istendik biçiminden hiç var olmadığı biçimine kadar çeşitlerini tanımlanmaktadır. $\mathrm{Bu}$ dizinin en istendik biçimi içsel motivasyondur. İçsel motivasyon, bireyin bir etkinliğe zevk, eğlence ve meraktan dolayı katılmaları durumunda gerçekleşir. Bu durumun tersinde dişsal motivasyon söz konusudur. Dişsal motivasyonun, dişsal düzenleme, içe yansıtılmış düzenleme, bütünleşmiş düzenleme ve özdeşimle düzenleme olarak dört ayrı biçimi bulunmaktadır. Dışsal düzenleme bireyin bir etkinliğe dışsal bir baskı, tehdit ya da ceza nedeniyle katılması durumunda oluşur ve motivasyonun en istenmeyen biçimidir. İçe yansıttılmış düzenleme, içsel baskı, suçluluk ve utanç hissi nedeniyle etkinliğe katılma durumunda; bütünleşmiş düzenleme bireyin etkinliği, bireysel hedef ve değerleriyle uyuştuğu için tercih ettiği durumlarda; özdeşimle düzenleme ise bireyin, o etkinliğin önemine ve faydasına inandığı durumlarda oluşur. Motivasyonsuzluk durumu bireyin etkinliğe katılması için içsel ya da dışsal hiçbir sebep olmadığında, etkinliğin önemine ya da istendik herhangi bir çıktısı olduğuna inanmadığı durumlarda oluşur (Deci ve Ryan, 2000).

Öz-Belirleme Kuramının beş alt kuramından bir tanesi olan Temel Psikolojik İhtiyaçlar Kuramı (Deci ve Ryan, 2000), bireylerin temel psikolojik ihtiyaçlarının sosyal çevre tarafından desteklenmesinin, bireylerin etkili bir biçimde işlevini yerine getirmesini ve gelişimini sürdürmesini sağladığını belirtmektedir (Bartholomew et al, 2011). Bireylerin üç farklı psikolojik ihtiyacı bulunmaktadır, bunlar; özerklik, yeterlik ve ilişkili olmadır. Bu üç temel psikolojik ihtiyaç, bireyin iyi olma hali, sosyal gelişimi, çevresiyle bütünleşme ve gelişmeye olan doğal eğiliminin işlevselliğini kolaylaştırmada temel teşkil eder (Deci ve Ryan, 2000). Özerklik, bireyin kendi eylemlerini içsel olarak onaylamasını ifade ederken; yeterlik, bireyin önemli çıtıtılar sağlayacak eylemlerde bulunma yeteneğine olan inancıdır; ilişkili olma ise bireyin sosyal çevreler ile tatmin edici ve destekleyici yaşantılara sahip olmasıdır (Stone, Deci ve Ryan, 2009). Deci ve Ryan'a (2000) göre, sosyal çevrenin ve bireysel farklılıkların özellikleri kullanılarak bireylerin ihtiyaçlarının tatmini ve sırasıyla deneyimlerinin kalitesi, davranışları ve sağlıkları tahmin edilebilir. Bu psikolojik ihtiyaçları tehdit eden sosyal çevreler, bireyleri fiziksel ve psikolojik riskler taşıyan hedeflere ve etkinliklere yönlendirebilir (Deci ve Ryan, 2000), motivasyonun ideal olmayan formlarının oluşmasını sağlayabilir ve bireyin iyi oluş (well-being) hali ile ilgili bozucu etkilere sebep olabilir (Deci ve Ryan, 2008). Aksine, bu ihtiyaçların tatmin edilmesini sağlayan sosyal çevreler, bireylerin fiziksel aktivite düzeylerini ve ideal motivasyon şekillerini destekler ve en olumlu psikolojik, gelişimsel ve davranışsal çıktıların ortaya çıkmasını sağlar (Ryan ve Deci, 2000).

Temel Psikolojik İhtiyaçlar Kuramına göre, ihtiyaçların tatmini özerklik desteğinin sağlandığı ortamlarda gerçekleşir; bu ortamlar bireylere seçenek sunulduğu, bireysel inisiyatifin cesaretlendirildiği, birbirleriyle ilişki içinde oldukları bir çevrede yeteneklerinin desteklendiği 
ortamlar olarak özetlenebilir (Deci ve di ̆. ., 2001). Özerkliği desteklenmiş bir ortam, bireylere etkinliğe katılım konusunda iyi bir gerekçe ve seçenekler sunar, bireylerin etkinlik konusundaki duygularını kabul eder, bireyin inisiyatif kullanmasını cesaretlendirir ve yetenekleri ile ilgili güven verir (Williams, Gagne, Ryan, ve Deci, 2002). Temel Psikolojik İhtiyaçlar Kuramının bir varsayımı, bireyin psikolojik ihtiyaçlarının, özerklik desteği ve optimal işlevsellik arasındaki ilişkiye aracılık ettiğidir. Temel Psikolojik İhtiyaçlar Kuramı ayrıca üç psikolojik ihtiyacı, algılanan sosyal çevre ve sağlıkı hissetme/hissetmeme durumu arasındaki ilişkiye aracı değişken olarak görmektedir (Deci ve Ryan, 2000). Varsayılan özerklik desteği, ihtiyaçların tatmini ve iyi oluş/psikolojik işlevselliğin belirtilerinin arasındaki ilişkiler farklı öğrenme ortamlarında desteklenmektedir. Bagøien ve arkadaşlarının (2010) beden eğitimi ortamında, Miquelon ve Vallerand (2006)'ın yüksek öğretim düzeyinde yaptığı çalışmalar buna örnek olarak verilebilir. Temel Psikolojik İhtiyaçlar alt kuramının temel ilkelerinden birisi, özerkliğin desteklenmesi, temel psikolojik ihtiyaçların tatmin edilmesi ve iyi olma halinin göstergelerinin farklı kültürlerde ve ortamlarda birbiri ile ilişkili olduğunu varsaymasıdır. Farklı kültürel gruplarda yapılmış çalışmalar bu varsayımı desteklemektedir (örn., Sheldon ve diğ., 2004).

Vallerand (1997), bir öğrenme ortamında sosyal etkenlerin örneğin öğretmenin sağladığ1 özerklik desteğinin, psikolojik aracı değişkenlerin yani temel psikolojik ihtiyaçların tatmininin, motivasyon çeşitlerinin, duyuşsal, bilişsel ve psikomotor farklı çıktılarının sırası ile birbirini etkilediğini ve bu durumun bir motivasyonel dizilim oluşturduğunu savunmuştur (Şekil 1).

\begin{tabular}{|c|c|c|c|}
\hline Sosyal Etkenler & $\rightarrow$ Psikolojik Aracılar & Motivasyon & Çıktılar \\
\hline $\begin{array}{l}\text { Örn. Özerklik } \\
\text { desteği }\end{array}$ & $\begin{array}{ll}\text { - } & \text { Özerklik ihtiyacı } \\
\text { - } & \text { Yeterlik ihtiyacı } \\
\text { - } & \text { Ilişkili olma ihtiyacı }\end{array}$ & $\begin{array}{l}\text { - İçsel motivasyon } \\
\text { - Bütünleşmiş düzenleme } \\
\text { - Özdeşimle düzenleme } \\
\text { - İçe yansit1lmış düzenleme } \\
\text { - Dişsal düzenleme } \\
\text { - } \quad \text { Motivasyonsuzluk }\end{array}$ & $\begin{array}{l}\text { - İyi oluş } \\
\text { - Duyuşsal } \\
\text { - Davranışsal } \\
\text { - Bilişsel } \\
\text { - Psikolojik }\end{array}$ \\
\hline
\end{tabular}

\section{Şekil 1. Vallerand (1997)'ın motivasyonel dizilimi}

Vallerand (1997)'ın motivasyonel dizilimini beden eğitimi ortamında test eden çalışmalar farklı kültürlerde yapılmıştır. Örneğin Ntoumanis (2001) 14-16 yaş grubu öğrencilerle yaptığı çalışmada içsel motivasyonun pozitif çıktılarla, dışsal düzenleme ve motivasyonun negatif çıktıların anlamlı bir yordayıcısı olduğunu ortaya koymuştur. Benzer şekilde Standage, Duda ve Ntoumanis (2003) ortaokul öğrencilerinde beden eğitimi derslerini ihtiyaç destekleyici nitelikte algılayan öğrencilerin temel psikolojik ihtiyaçlarının da geniş bir etki büyüklüğünde yordandığını, ihtiyaç tatmininin ise içsel motivasyonu yordadığını ve bu durumun olumlu çıktılar sağladığını ortaya koymuşlardır. Standage ve Gillison (2007) motivasyonel dizilimin özsaygı ve sağlıkla ilişkili yaşam kalitesi çıktıları ile pozitif ilişkisini ortaya koymuşlardır. Cox, Duncheon ve McDavid (2009) lise öğrencilerinde motivasyonel dizilimde öğrenci kaygısı ve eğlenme düzeyi duyuşsal çıktılarını incelemişler ve modeli anlamlı bulmuşlardır. Ommundsen ve Kvalo (2007) 10. sınıf öğrencileri ile yaptıkları çalışmada beden eğitimi ders ortamında öğretmenin özerklik desteğinin öğrencilerin temel psikolojik ihtiyaçlarının tatmininin tahmin edicisi, bunun da içsel motivasyonun pozitif tahmin edicisi olduğunu ortaya koymuşlardır. 
Vallerand (1997)'in motivasyonel diziliminin çıktısı olarak bireyin psikolojik iyi oluş durumunun etkilendiğini ortaya koyan çalışmalar farklı değişkenlere odaklanmışlardır. Örneğin Sheikhi Fini ve arkadaşları (2010), üniversite öğrencilerinde psikolojik iyi oluş halinin, yaşam becerilerinin ve yaşam doyumunun sırasıyla öznel zindeliğin en güçlü yordayıcıları olduğunu ortaya koymuşlardır. Reinboth ve arkadaşları (2004) ise ergen erkek sporcu örnekleminde, antrenör tarafından yaratılan ortamın farklı yönlerinin (örn., algılanan özerklik desteği, görevde ustalaşmaya odaklı ve sosyal destekleyici özellikler), özerklik, yeterlik ve ilişkili olmanın olumlu tahmin edicileri olduğunu bulmuşlardır. Özerklik ve yeterlik algısı, seçili sporda öznel zindelik ve içsel ilgi ile pozitif ilişkilidir. Temel ihtiyaçların, algılanan özerklik desteği ve öznel zindelik arasındaki ilişkideki varsayılan aracı rolü kısmen desteklenmektedir. Adie, Duda ve Ntoumanis'in (2012) boylamsal çalışmalarında elit genç futbol ortamında antrenör tarafından sağlanan özerklik desteğinin, temel ihtiyaçların tatmini ve iyi oluş halinde bireyin zaman içinde kendi içindeki değişiminde ve bireylerarası değişimde pozitif yordayıcı olduğu bulunmuştur. Yeterlik ve ilişkili olma ihtiyaçlarının tatmininin antrenörün sporcularına sağladığı özerklik desteği ve sporcuların öznel zindelik düzeyleri arasındaki ilişkiye aracılık ettiği belirlenmiştir. Taylor ve Lonsdale (2010), öğrencilerin beden eğitimi dersinde öğretmenlerinden algıladıkları özerklik desteği ile psikolojik ihtiyaçların tatmini, öznel zindelik ve sınıf içinde çaba harcama arasındaki ilişkide kültürel farklılıklar olduğunu tespit etmişlerdir. İngiliz, Hong Konglu ve Çinli öğrencilerin katıldığı çalışmada, özerklik desteği ile öznel zindelik ve çaba arasındaki ilişkide öğrencilerin psikolojik ihtiyaçlarının aracılık rolü anlamlı bulunmuştur. Özerklik desteği ve yeterlik algısı arasındaki ilişki, Çinli örneklemde, İngiliz örnekleme kıyasla daha yüksektir. $\mathrm{Bu}$ bulgu da söz konusu modelin kültürlerarası çalışmalarda farklı boyutları öne çıkardığına işaret etmektedir.

Vallerand (1997)'ın motivasyonel dizilimini beden eğitimi dersi yapısında Türk kültüründe test eden çalışmaya rastlanmamıştır. Bunun yanında bu çalışmada, ergenlik dönemindeki öğrencilerde olumsuz değerlendirilme korkusu, sosyal görünüş kaygısı, öznel zindelik ve konsantrasyon değişkenleri aracılığı ile ölçülen psikolojik iyi oluşun belirleyicilerinin bilinmesi de beden eğitimi öğretmenlerine önemli bilgiler sağlayabilir. Bu doğrultuda bu çalışma, Vallerand (1997)'nn motivasyonel dizilimini temel almış ve beden eğitimi derslerinde psikolojik iyi oluşun pozitif ve negatif göstergeleri olan olumsuz değerlendirilme korkusu, konsantrasyon, sosyal görünüş kaygısı ve zindeliğin, öğretmen tarafından sağlanan özerklik desteği, temel psikolojik ihtiyaçların tatmini ve derse ilişkin içsel motivasyon tarafından ne kadar açıklandığını belirlemeyi amaçlamıştır. Hipotez yol modeli şekil 2'de verilmiştir. 


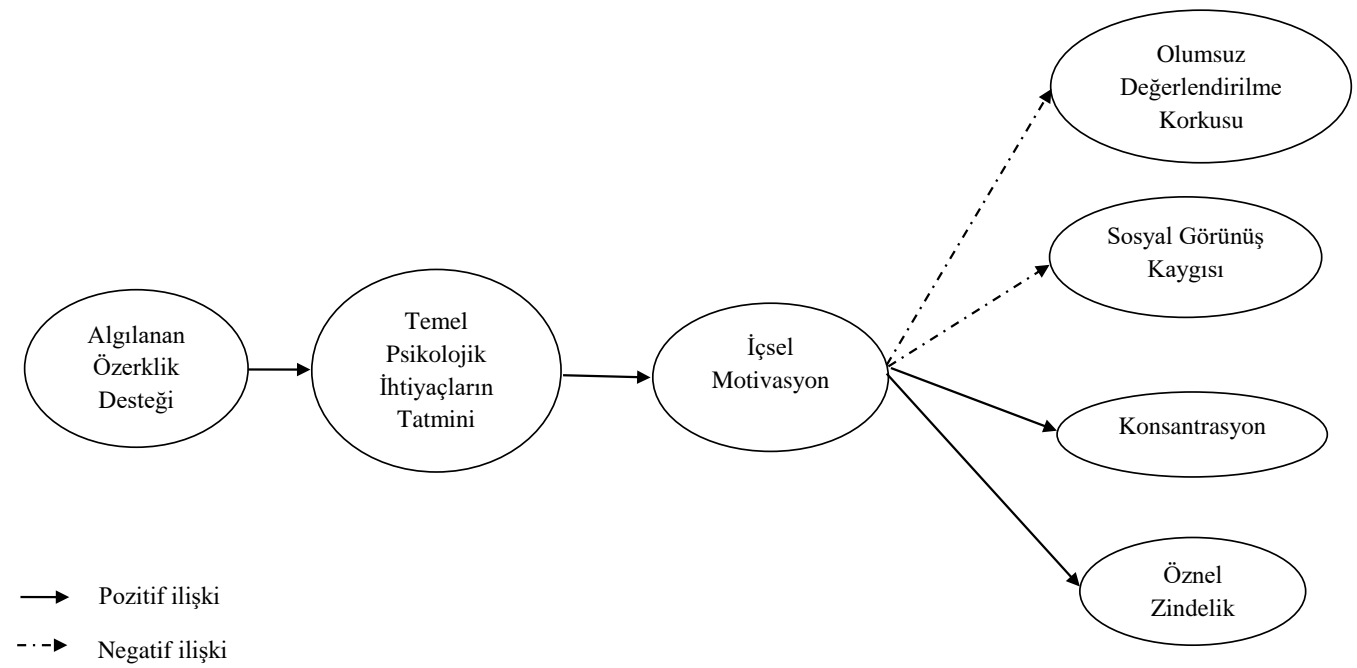

Şekil 2. Hipotez yol analizi modeli

\section{Yöntem}

\section{Araștırma Grubu}

Araştırma iki ayrı devlet okulunda toplam sekiz ayrı sınıfta öğrenim gören 431 lise öğrencisinden toplanmıştır. Beden eğitimi derslerine düzenli olarak katılan toplam 431 lise öğrencisi (\%51,74 kız, \%48,25 erkek) çalışmaya gönüllü olarak katılmıştır. Katılımcıların sınıf düzeylerine ve cinsiyete göre dağılımları Tablo 1'de verilmiştir.

Tablo 1. Katılımcıların Cinsiyete ve Sınıf Düzeyine Göre Dağılımı

\begin{tabular}{lcccccc}
\hline & \multicolumn{3}{c}{ Sinıf Düzeyi } & & \multicolumn{2}{c}{ Toplam } \\
\hline & 9 & & 11 & & $\%$ \\
K1z & $\mathrm{N}$ & $\%$ & $\mathrm{~N}$ & $\%$ & $\mathrm{~N}$ & 51.74 \\
Erkek & 123 & 55.15 & 100 & 44.84 & 223 & 48.25 \\
Toplam & 118 & 56.73 & 90 & 43.26 & 208 & 100 \\
\hline
\end{tabular}

\section{Veri Toplama Araçları}

Çalışmada kullanılan olan tüm ölçme araçları daha önce benzer örneklem gruplarında geçerlik ve güvenirlik çalışmaları yapılmış ölçeklerdir. Öğrencilerin cinsiyet ve sınıf düzeylerini sorgulayan sorular ölçek paketinin başında yer almıştır. 


\section{Temel psikolojik ihtiyaç tatmini}

Öz-belirleme kuramının temel kavramlarından olan temel psikolojik ihtiyaçların ölçümünde, orijinali Deci ve Ryan (2000) tarafından geliştirilmiş, Bacanlı ve Cihangir-Çankaya (2003) tarafindan Türkçeye uyarlanmış Temel Psikolojik İhtiyaç Doyumu Ölçeği (Basic Psychological Need Satisfaction Scale) kullanılmıştır. Ölçekte bireyin üç temel psikolojik ihtiyacını ölçen 21 madde bulunmaktadır. Özerklik (autonomy), yeterlik (competence) ve ilişkili olma (relatedness) olmak üzere üç alt boyuttan oluşmaktadır. Özerklik alt ölçeğinde yedi, yeterlik alt ölçeğinde altı, ilişkili olma alt ölçeğinde ise sekiz madde bulunmaktadır. Her alt ölçekteki maddelerin puanlarının toplanması ile alt ölçek puanları, bütün ölçeğin puanlarının toplanması ile de toplam puan elde edilmektedir. Ölçek yedili derecelendirmeye $(1=$ Hiç doğru değil, 7 = Çok doğru $)$ sahiptir. Ölçeğin her alt boyutundan alınan puan arttıkça üç temel ihtiyacın tatmininin o düzeyde arttığı anlamına gelmektedir. Ölçeğin, bu çalışmada yapılan doğrulayıcı faktör analizi sonuçları, ölçeğin istenen uyum indekslerini sağladığını göstermiştir $(\chi 2 / \mathrm{sd}=2.44$; GFI = 0.93; AGFI = 0.91 ; CFI $=0.90$; RMSEA $=0.06)$ ve iç tutarlık $(\alpha=0.71)$ düzeyi yeterli bulunmuştur (Nunnally, 1978).

\section{Olumsuz değerlendirilme korkusu}

Araştırmada, Olumsuz Değerlendirilme Korkusu Ölçeği (Fear of Negative Evaluation Scale) Kısa Formu kullanılmıştır. Form, Leary 1983) tarafindan bireyin başkaları tarafından olumsuz ya da düşmanca değerlendirilmeye karşı toleransını ölçmeye yönelik olarak geliştirilmiş özbildirim tarzı bir ölçektir. Ölçek, 11 maddelik tek boyuttan oluşmakta ve beşli derecelendirmeye sahip (1 = Hiç uygun değil, 5 = Tamamen uygun) bir ölçektir. Ölçekten alınan puanın yüksek olması, bireyin olumsuz değerlendirilme korkusunun arttığı şeklinde yorumlanmaktadır. Ölçeğin, bu çalışmada yapılan doğrulayıcı faktör analizi sonuçları, ölçeğin istenen uyum indekslerini sağladığını göstermiştir $(\chi 2 / \mathrm{sd}=3.58 ; \mathrm{GFI}=0.94 ;$ AGFI $=0.91 ; \mathrm{CFI}=0.94$; RMSEA $=0.08)$ ve iç tutarlık düzeyi $(\alpha=0.72)$ yeterli bulunmuştur (Nunnally, 1978).

Sosyal Görünüş Kaygısı: Sosyal Görünüş Kaygısı Ölçeği (Social Appearance Anxiety Scale), Hart ve ark. (2008) tarafından geliştirilmiş 16 maddelik beşli derecelendirmeye sahip (1 = Hiç uygun değil, 5 = Tamamen uygun) bir ölçektir. Örnek madde "Görünüşümden dolayı insanların benimle beraber vakit geçirmek istemeyeceklerinden endişelenirim." Ölçek, tek faktörden oluşmaktadır. Ölçekten alınan puanın yüksek olması, bireyin sosyal görünüş kaygısının arttığı şeklinde yorumlanmaktadır. Ölçeğin Türkçe geçerlik ve güvenirlik çalışması Doğan (2009) tarafından gerçekleştirilmiştir. Yapı geçerliğini belirlemek amacıyla bu çalışmada yapılan doğrulayıcı faktör analizi sonuçları, istenen uyum indekslerini sağladığını göstermiştir $(\chi 2 / \mathrm{sd}=2.12 ; \mathrm{GFI}=0.93 ; \mathrm{AGFI}=0.92 ; \mathrm{CFI}=0.97 ; \mathrm{RMSEA}=0.05)$ ve iç tutarlık düzeyi $(\alpha=$ 0.82 ) yeterli bulunmuştur (Nunnally, 1978).

\section{İçsel motivasyon}

Öğrencilerin beden eğitimi derine ilişkin içsel motivasyon düzeyleri Durumsal Güdülenme Ölçeğinin (Situational Motivation Scale) içsel güdülenme alt ölçeği aracılığıyla ölçülmüştür. Ölçek, Guay, Vallerand ve Blanchard (2000) tarafından geliştirilmiştir. Durumsal Güdülenme Ölçeği yargıların 7 yedili derecelendirmeye göre göre yapıldığı (1= Bütünüyle uygun değil - 7= Bütünüyle uygun), 16 maddeden oluşmakta ve dört alt ölçeği içermektedir. İçsel güdülenme alt ölçeği için örnek madde "Bu dersi yaparken kendimi iyi hissettiğim için". Ölçeğin spor ve 
fiziksel aktivite ortamları için Türkçe uyarlaması Kazak Çetinkalp (2010) tarafindan kadın ve erkek toplam 470 sporcu üzerinde gerçekleştirilmiştir. Durumsal Güdülenme Ölçeği'nin beden eğitimi ders ortamlarına uygun hale getirilme aşamasında, ölçek maddelerinin başında ki soru olan "Niçin şu anda bu aktiviteye katılıyorsunuz?" ifadesi değiştirilerek, yerine "Şu anki Beden Eğitimi dersine neden katılıyorsunuz?" ifadesi kullanılmıştır. Ayrıca, maddelerde geçen "aktivite" kelimesi, "beden eğitimi" ifadesi ile değiştirilmiştir. Ölçeğin her alt boyutundan alınan puanın artması beden eğitimi dersine ilişkin içsel motivasyonun artması anlamına gelmektedir. Ölçeğin, bu çalışmada yapılan doğrulayıcı faktör analizi sonuçları, ölçeğin istenen uyum indekslerini sağladığını göstermiştir $(\chi 2 / \mathrm{sd}=3.282$; GFI $=0.943 ;$ AGFI $=0.912 ; \mathrm{CFI}=$ $0.958 ;$ RMSEA $=0.073)$ ve iç tutarlık düzeyi $(\alpha=0.74)$ yeterli bulunmuştur (Nunnally, 1978).

\section{Özerklik desteği}

Öğrencilerin algılanan öğretmenin yarattığı özerklik desteği, Sağlık Hizmetleri İklimi Ölçeğinden (Health Care Climate Questionnaire; Williams ve diğ., 1996) seçilmiş maddeler ile ölçülmüştür. Ölçek yedili derecelendirmeye $(1=$ Tamamen katılmıyorum, 7 = Tamamen katılıyorum) sahiptir. Türkçe uyarlaması ikinci yazar tarafından yapılmıştır. Ölçekte öğrencilerin dönem başladığından beri beden eğitimi derslerinde kendilerini ne kadar enerjik hissettiklerine dair maddeler yer almaktadır. Ölçekten alınan puanın artması, öğrencilerin beden eğitimi derslerindeki algıladıkları öğretmen kaynaklı özerklik desteğinin artması şeklinde yorumlanmaktadır. Ölçeğin, bu çalışmada yapılan doğrulayıcı faktör analizi sonuçları, ölçeğin istenen uyum indekslerini sağladığını göstermiştir $(\chi 2 / \mathrm{sd}=2.316$; GFI = 0.989; AGFI = 0.968; $\mathrm{CFI}=0.994$; RMSEA $=0.055)$ ve iç tutarlık düzeyi $(\alpha=0.89)$ yeterli bulunmuştur (Nunnally, 1978).

\section{Konsantrasyon}

Öğrencilerin, dönem başından beri beden eğitimi derslerinde, verilen görevlere ne kadar konsantre olduklarını sorgulayan ve altı maddeden oluşan ölçek (Concentration; Standage, Duda ve Ntoumanis, 2005) ikinci yazar tarafından Türkçeye uyarlanmıştır. Beşli derecelendirmeye sahiptir. Ölçekten alınan puanın artması, öğrencilerin beden eğitimi derslerindeki konsantrasyon düzeyinin artması şeklinde yorumlanmaktadır. Yap1 geçerliğini belirlemek amacıyla bu çalışmada yapılan doğrulayıcı faktör analizi sonuçları, istenen uyum indekslerini sağladığını göstermiştir $(\chi 2 / \mathrm{sd}=3.10 ; \mathrm{GFI}=0.98 ; \mathrm{AGFI}=0.95 ; \mathrm{CFI}=0.98 ; \mathrm{RMSEA}=0.07)$ ve iç tutarlık düzeyi ( $\alpha=0.75)$ yeterli bulunmuştur (Nunnally, 1978).

\section{Öznel zindelik}

Öznel zindeliği ölçmek için kullanılan Öznel Zindelik Ölçeği (Subjective Vitality Scale; Ryan ve Frederick, 1997) yedi maddeden oluşmaktadır. Ölçek yedili derecelendirmeye (1= Bana hiç uymuyor, 7 = Bana tamamen uyuyor) sahiptir. Türkçe uyarlaması araştırmacılar tarafından yapılmış ve açımlayıcı faktör analizi sonuçları, KMO değerinin 0,893, Barlett Testinin ise anlamlı olduğunu $\left(\mathrm{X}^{2}=1303,020 ; \mathrm{sd}=21, \mathrm{p}=0,000\right)$ ortaya koymuştur. Ölçeğin tek boyutlu yapısının faktör yük değerlerinin 0,66 ile 0,86 arasında değişmiştir. Doğrulayıcı faktör analizi sonuçları iyi uyum değerleri gösterdiğini ortaya koymuştur $(\chi 2 / \mathrm{sd}=2,912$; GFI $=0,974$; AGFI $=0,947 ; \mathrm{CFI}=0,979 ; \mathrm{RMSEA}=0,067$ ). Ölçeğin iç tutarlık katsayısı 0,85 bulunmuştur. Ölçekte öğrencilerin dönem başladığından beri beden eğitimi derslerinde kendilerini ne kadar enerjik hissettiklerine dair maddeler yer almaktadır. Ölçekten alınan puanın artması, öğrencilerin beden 
eğitimi derslerinde kendilerini zinde ve enerjik hissetme düzeyinin artması şeklinde yorumlanmaktadır. Ölçeğin, bu çalışmada yapılan doğrulayıcı faktör analizi sonuçları, ölçeğin istenen uyum indekslerini sağladığını göstermiştir $(\chi 2 / \mathrm{sd}=2.91$; GFI $=0.97$; AGFI $=0.94$; CFI $=0.98 ;$ RMSEA $=0.07)$ ve iç tutarlık düzeyi $(\alpha=0.88)$ yeterli bulunmuştur (Nunnally, 1978).

\section{Verilerin Toplanması}

Üniversite Etik Kurulu'ndan ve İl Milli Eğitim Müdürlüğü’nden gerekli izinler alınmıştır. Veri toplanacak olan iki ayrı lisenin okul müdürlerine, öğrencilere ve velilere bilgi formlan dağıtılarak araştırmanın amacı açıklanmıştır. Yalnızca çalışmaya gönüllü olarak katılmayı kabul eden öğrencilerden veri toplanmıştır. Ölçekler sınıf ortamında uygulanmış, uygulama öncesinde öğrencilere, istedikleri zaman çalışmadan çekilebilecekleri, yanıtlarının öğretmen ya da velileri ile paylaşılmayacağı ve doğru ya da yanlış cevap olmadığı açıklanmıştır. Araştırmadan çekilmek isteyen ya da katılmak istemeyen öğrenci olmamıştır. Öğrencilerin ölçekleri doldurmaları ortalama 30 dakika sürmüştür.

\section{Verilerin Analizi}

Her bir ölçek için orijinallerindeki faktör yapılarının bu veri setinde doğrulanıp doğrulanmadığını belirlemek için doğrulayıcı faktör analizi yapılmıştır. Her bir ölçeğin ve alt ölçeklerin iç tutarlığını test etmek için Cronbach's alpha değerleri hesaplanmıştır. Ayrıca ortalama değer, standart sapma vb. betimsel istatistiklerden yararlanılmıştır. Lise öğrencilerinin, çalışmanın veri toplama araçlarına ön ve son test olarak verdikleri yanıtlardan her bir ölçek için elde edilen toplam puanlar yardımı ile değişkenler arası karşılıklı ilişkiler Yol Analizi (Path Analysis) aracılığı ile test edilmiştir. Elde edilen veriler ile Yol Analizi ile ortaya konan model arasındaki uyum, bazı uyum değerleri ile değerlendirilmiştir. Bunlar, ki kare değerinin serbestlik derecesine bölümü $(\chi 2 / s d)$, comparative fit index (CFI), goodness of fit index (GFI), adjusted goodness of fit index (AGFI), root mean square error of approximation (RMSEA) değerleridir. Ki kare değerinin serbestlik derecesine bölümünün üçün altında olması, GFI ve AGFI değerlerinin 0.90 'ın üstünde olması ve RMSEA değerinin 0.80'in altında olması durumunda veri ile model arasında iyi uyum olduğu varsayılmaktadır (Cole ve Maxwell, 1985). Yol Analizi öncesinde veri setini analize hazır hale getirmek için eksik değerler belirlenmiştir. Değişkenlerinde \%5'in üzerinde boş değer olan beş kişiye ait veri, veri setinden çıkarılmıştır. Ardından tek değişkenli uç değerlerin tespit edilmesi amacıyla çalışmaya dahil edilen tüm değişkenler için standardize $\mathrm{z}$ skorları hesaplanmış tek değişkenli uç değere sahip olduğu belirlenen beş veri, veri setinden çıkarılmıştır. Bunun ardından Mahalanobis uzaklık değerleri yardımıyla çok değişkenli uç değerler belirlenmiş ve iki veri, veri setinden çıkarılmıştır (Tabachnick ve Fidell, 2007). Ön analizler sonrasında veri setinde kalan 431 veri, normallik, doğrusallık, varyansların homojenliği açısından test edilmiş ve veri setinin söz konusu sayıltıları karşıladığ1 görüldükten sonra Yol Analizi uygulanmıştır (Tabachnick ve Fidell, 2007).

\section{Bulgular}

Araştırma grubundan toplanan verilere ilişkin tanımlayıcı değerler incelenmiştir. Tablo 2'de değişkenlere ilişkin tanımlayıcı değerler ve Cronbach Alpha değerleri görülmektedir. 
Tablo 2. Değişkenlere Illişkin Ortalama, Standart Sapma, Skewness ve Kurtosis Değerleri

\begin{tabular}{lccccc}
\hline & Ölçek Aralı̆̆ & $\overline{\boldsymbol{X}}$ & Ss & Skewness & Kurtosis \\
\hline Olumsuz değerlendirilme korkusu & $1-5$ & 2.75 & .42 & .157 & .338 \\
Konsantrasyon & $1-5$ & 3.57 & .80 & .866 & 1.820 \\
Sosyal görünüş kaygısı & $1-5$ & 2.21 & .80 & .893 & .118 \\
İçsel Motivasyon & $1-7$ & 4.85 & 1.55 & -.656 & -.339 \\
Zindelik & $1-7$ & 4.67 & 1.22 & -.444 & -.198 \\
Özerklik desteği & $1-7$ & 4.88 & 1.57 & -.646 & -.206 \\
Temel psikolojik ihtiyaçlar & $1-7$ & 4.27 & .45 & .224 & 1.047 \\
\hline
\end{tabular}

Çalışmaya dahil edilen tüm ölçek/alt ölçeklere ait skewness ve kurtosis değerlerine bakıldığında çalışmaya dahil edilen değişkenlerin normal dağılım gösterdiği görülmektedir.

Beden eğitimi öğretmenlerinin sağladığı öğrenme ortamlarındaki özerklik desteği, temel psikolojik ihtiyaçların tatmini ve öğrencilerin psikolojik iyi oluş göstergeleri arasındaki karşılıklı ilişkileri ortaya koymak amacı ile Yol Analizi yapılmış, modelin uyum indeksleri Tablo 4'te verilmiştir. Görsel yalınlığı sağlamak amac1 ile Şekil 3'te gösterilen modelde yalnızca istatistiksel olarak anlamlı olan etkiler gösterilmiştir.

Tablo 4. Yapısal Modelin Uyum İndeksleri

\begin{tabular}{lc}
\hline Uyum İndekslerinin Kabul Edilme Aralıkları & Elde Edilen Uyum İndeksleri \\
\hline$\chi 2 /$ sd $<5$ & 1.726 \\
GFI $>0.90$ & 0.981 \\
AGFI $>0.90$ & 0.966 \\
CFI $>0.90$ & 0.982 \\
RMSEA $<0.08$ & 0.041 \\
\hline
\end{tabular}

Modelin uyum indeksleri incelendiğinde GFI, CFI ve AGFI değerlerinin kabul edilebilir değer olan 0.90 'dan yüksek olduğu, RMSEA değerinin 0.08 'in altında olduğu görülmektedir. Buna göre bir bütün olarak incelenen yapısal modelin veriye uygun olduğu söylenebilir. 


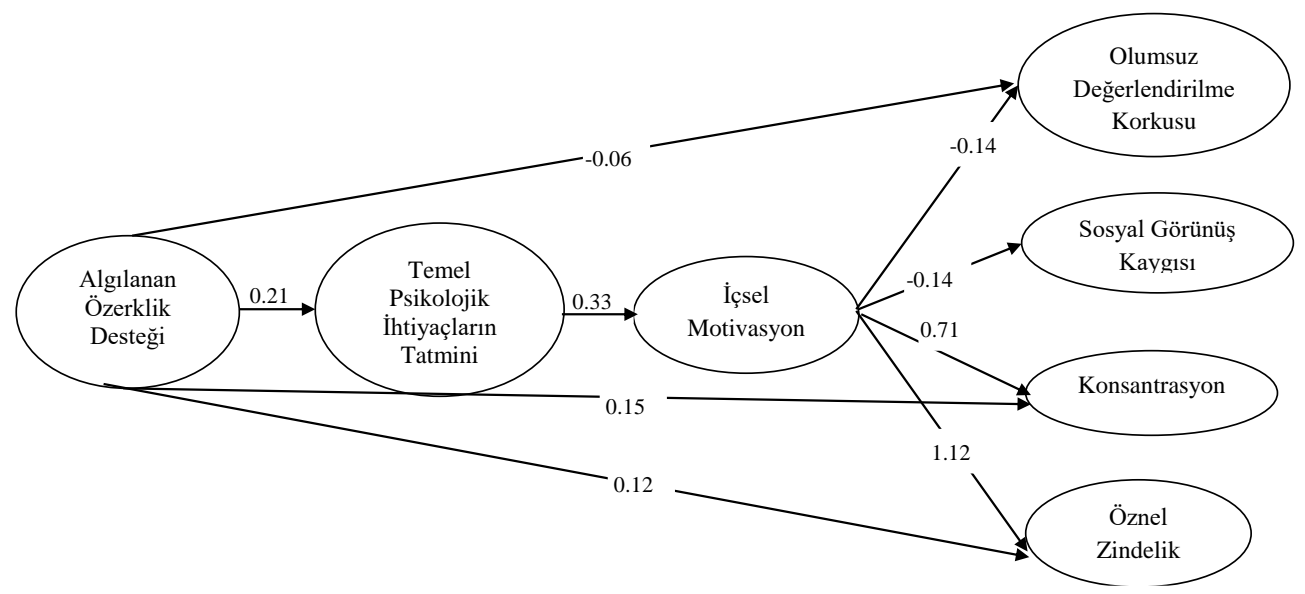

\section{Şekil 3. Yol analizi modeli}

Yol Analizinde değişkenler arası yollardan elde edilen katsayılar Şekil 3'te görülmektedir. Algılanan özerklik desteği, temel psikolojik ihtiyaç tatminini, temel psikolojik ihtiyaç tatmini ise, içsel motivasyonu anlamlı düzeyde artırmaktadır $(\mathrm{p}<0.05)$. İçsel motivasyon, konsantrasyonu ve öznel zindeliği anlamlı olarak artırmakta, olumsuz değerlendirilme korkusu ve sosyal görünüş kaygısını anlamlı düzeyde azaltmaktadır $(\mathrm{p}<0.05)$. Ayrıca algılanan özerklik desteği doğrudan konsantrasyonu ve öznel zindeliği artırmakta, olumsuz değerlendirilme korkusunu azaltmaktadır $(\mathrm{p}<0.05)$. Modelde, olumsuz değerlendirilme korkusundaki varyansın $\% 8$ 'i, sosyal görünüş kaygısındaki varyansın \%4'ü, konsantrasyondaki varyansın \%36'sı ve öznel zindelikdeki varyansın \%44'ü açıklanmaktadır.

\section{Tartışma ve Sonuç}

Bu araştırma, Temel Psikolojik İhtiyaçlar Kuramının önemli bir varsayımını test etmiş ve derste öğretmenin yarattığı özerklik desteğinin, öğrencilerin üç temel psikolojik ihtiyacını açıkladığını, temel psikolojik ihtiyaç tatmininin öğrencilerin içsel motivasyon düzeylerini açıkladığını ve bu ilişkinin de öğrencilerin olumsuz değerlendirilme korkusu ve sosyal görünüş kaygısı düzeylerini negatif yönde, öznel zindelik ve konsantrasyon düzeylerini ise pozitif yönde açıkladığını ortaya koymuştur. Bu bağlamda, öğretmenin beden eğitimi derslerinde öğrencilere özerk bir öğrenme ortamı sunmasının, temel psikolojik ihtiyaçlarının tatmin edilmesi aracılığı ile öğrencilerin içsel motivasyon düzeylerini artırdığı ve psikolojik olarak iyi oluşlarına katkı sağladığı söylenebilir. $\mathrm{Bu}$ bilgi eğitimcilerin, ergenlik dönemindeki öğrenciler için daha uyumlu öğrenme ortamları oluşturarak, onların temel psikolojik ihtiyaçlarını ve optimal işlevselliklerini nasıl destekleyeceklerini öğrenmelerine olanak sağlaması bakımından değerlidir.

Öğrencilerin beden eğitimi derslerine ilişkin motivasyonlarını etkileyen faktörleri belirlemek önemlidir. Çünkü beden eğitimi derslerinde öğrencilerin dışsal motive olmalarının dersten sikılma ve derste mutsuz olma (örn, Ntoumanis, 2001; Standage, Duda ve Ntoumanis, 2005), derse katılımda düşüş (Aelterman ve diğ., 2012) ve buna bağlı olarak da okul dışındaki zamanlarında da fiziksel olarak aktif olmada düşüş (Brunet ve Sabiston, 2009; Haerens ve diğ., 2010) ile ilişkili olduğu bilinmektedir. Bunun yanında özerk motivasyonun derste çaba göstermeyi, motivasyonsuzluğun ise etkinliklere katılımda azalmayı yordadığı bilinmektedir (Cox, Ullrich-French, Madonia ve Witty, 2011). Öğrencilerin beden eğitimi derslerine ilişkin 
motivasyonlarını ve buna bağlı olarak da pek çok bilişsel ve duyuşsal öğrenci çıtısını ele alan çalışmalara sınırlı sayıda olmakla birlikte farklı kültürlerde rastlanmaktadır. Örneğin Yli-Piipari ve diğerleri (2009), beden eğitimi dersinden en çok zevk alan grupların yüksek içsel motivasyon ile düşük motivasyonsuzluk düzeyine sahip öğrencilerden oluştuğunu ortaya koymuşlardır. Ancak Türkiye'de Vallerand (1997)'ın ortaya koymuş olduğu motivasyonel dizilimin tamamını beden eğitimi ortamında test eden bir çalışma bulunmamaktadır. $\mathrm{Bu}$ nedenle bu özelliği bakımından çalışma, bir ilk niteliğindedir. Araştırma, ergenlik dönemini kapsayan lise eğitimi boyunca öğrencilerin beden eğitimi derslerine katılmalarına motive olmalarını etkileyen etmenlerin derinlemesine analizine olanak sağlamıştır. Beden eğitimi öğretmenlerinin ders içerisinde özerklik desteğini ne ölçüde sağladıklarına paralel olarak öğrencilerin temel psikolojik ihtiyaçlarının ne oranda karşılandığı ve devamında da bundan etkilenen birçok psikolojik ve bilişsel değişkenin ne yönde etkilendiği belirlenmiştir.

Çalışmaya, test edilen modelde motivasyonel dizilimin çıktı değişkenleri olarak olumsuz değerlendirilme korkusu, sosyal görünüş kaygısı, konsantrasyon ve öznel zindelik değişkenleri dahil edilmiştir. Özerklik desteği sağlandığında öğrencilerin temel psikolojik ihtiyaç doyumunun arttığ1 ve böylece öznel zindelik düzeylerinin arttığ1 görülmüştür. Öznel zindelik kişinin kendisinden kaynaklı yüksek pozitif enerji durumu olarak tanımlandığı (Ryan ve Frederick 1997) için, öğrencilerin fiziksel olarak aktif oldukları bir ders olan beden eğitimi derslerinin verimi açısından oldukça önemlidir. Beden eğitimi ders ortamında zindelikle ilgili araştırma sayısı oldukça sınırlıdır. Taylor ve Lonsdale (2010), beden eğitimi öğretmeninin sağladığı özerklik desteğinin öğrencilerin temel psikolojik ihtiyaçlarını, bunun da öznel zindelik ve çaba ile ilişkili olduğunu belirlemişlerdir. Spor ortamında yapılan çalışma sonuçları da zindeliğin, özerklik ve psikolojik ihtiyaç tatminiyle ilişkisini desteklemektedir. Örneğin Adie, Duda ve Ntoumanis (2008) yetişkin sporcularla yaptıkları çalışmada antrenman ortamında antrenörün düşük düzeyde özerklik desteği sağlanmasının sporcuların duygusal ve fiziksel yorgunluk düzeylerini artırdığını, özerklik ve yeterlik ihtiyaçlarının bu ilişkiye kısmi aracılık ettiğini ortaya koymuşlardır. Benzer şekilde Bartholomew, Ntoumanis, Ryan, Bosch ve Thøgersen-Ntoumani (2011) sporcularda antrenman ve maç ortamlarında temel psikolojik ihtiyaç doyumu sağlandığında zindeliğin, ihtiyaç doyumu sağlanmadığında ise yeme bozukluğu, tükenmişlik, depresyon ve olumsuz bazı fiziksel semptomların oluştuğunu belirlemişlerdir.

$\mathrm{Bu}$ araştırmadan elde edilen sonuçlar, öğretmen tarafından sağlanan özerklik desteğinin, temel psikolojik ihtiyaç doyumunu ve içsel motivasyonu artırarak sosyal fizik kaygıyı düşürücü etki yaptığını ortaya koymuştur. Öğrencilerin tüm akranlarının önünde bedeni ile bir performans sergilemesine dayalı yapısı gereği, beden eğitimi derslerinde özellikle ergenlik dönemindeki kız öğrencilerin sosyal görünüş kaygısının arttığı bilinmektedir (Sabiston, Sedgwick, Crocker, Kowalski ve Mack, 2007). Cox, Ullrich-French ve Sabiston (2013) lise düzeyinde beden eğitimi derslerinde yüksek sosyal fizik kaygının dersten zevk almama ve çaba göstermeme ile ilişkisini ortaya koymuşlardır. Eğer öğrenciler sosyal fizik kaygının yanı sıra dışsal motivasyona da sahiplerse beden eğitimi dersi ile birlikte okul dışındaki serbest zamanlarda da fiziksel aktiviteden zevk almamışlar ve çaba göstermemişlerdir. Brunet ve Sabiston (2009) sosyal fizik kaygının bireylerin üç temel psikolojik ihtiyacını da olumsuz etkilediğini ve bu yolla da fiziksel aktivite motivasyonunu ve davranışını azalttığını ortaya koymuşlardır. Benzer şekilde Cox, Ullrich-French, Madonia ve Witty (2011) beden eğitimi derslerinde sosyal fizik kaygının özerk motivasyonun negatif tahmin edicisi, dışsal motivasyon ve motivasyonsuzluğun ise pozitif 
tahmin edicisi olduğunu, bunun yanı sıra arkadaşlar tarafindan kabul görmenin sosyal fizik kaygının negatif tahmin edicisi olduğunu belirlemiş̧lerdir. Tüm bu olumsuz etkileri göze alınarak özellikle beden eğitimi derslerinde ergenlik dönemindeki öğrencilerin sosyal görünüş kaygılarını azaltmanın yolları aranmalıdır.

Psikolojik iyi oluşun negatif bir bileşeni olarak olumsuz değerlendirilme korkusu çalışmaya dahil edilmiştir. Bireylerin psikolojik iyi oluşunu olumsuz etkilediği bilinen olumsuz değerlendirilme korkusunun, beden eğitimi ders ortamında öğrencilerin dersin gerektirdiği fiziksel performansı sergilemesi sırasında akranları ve öğretmeni tarafından desteklenmesi olasıdır. Bu araştırmada beden eğitimi ortamında öğretmen tarafindan sağlanan özerklik desteği ve öğrencinin içsel motivasyonunun, olumsuz değerlendirilme korkusunu azalttı̆g 1 görülmüştür. Üniversite öğrencilerinde yapılan bir çalışmada da olumsuz değerlendirilme korkusunun, utangaç olma ve ebeveynlerin disiplinli ve denetleyici olmaları arasındaki ilişkide aracı değişken olduğu bulunmuştur (Koydemir-Özden ve Demir, 2009).

Araştırmaya dahil edilen konsantrasyon değişkeni, beden eğitimi derslerinde çoğunlukla ikinci plana atılan bilişsel alan davranışlarından biridir. Fiziksel performansın ön planda tutulduğu bir ders olan beden eğitiminde duyuşsal ve bilişsel alan davranışlarının da kazanımı hedeflenmelidir. Standage, Duda ve Ntoumanis (2005), beden eğitimi derslerinde ortaokul düzeyindeki öğrencilerin temel psikolojik ihtiyaçları karşılandığında içsel motivasyonlarının arttığını, içsel motivasyonun da dersteki konsantrasyon düzeyini artırdığını belirlemişlerdir. Benzer şekilde Ntoumanis (2005), beden eğitimi derslerinde ergenlik dönemindeki öğrencilerin temel psikolojik ihtiyaçları tatmin edildiğinde, öğrencilerin derse ilişkin özerk motivasyonlarının ve dersteki konsantrasyon düzeylerinin arttığını ortaya koymuştur. Bu çalışmadan elde edilen bulgular da sınırlı sayıdaki araştırma sonuçlarını destekler niteliktedir. Öğretmen tarafindan sağlanan özerklik desteği doğrudan ve öğrencilerin temel psikolojik ihtiyaçlarını ve içsel motivasyonlarını artırmak yolu ile dolaylı olarak öğrencilerin konsantrasyon düzeyini artırmıştır.

Vallerand (1997)'ın motivasyonel diziliminin beden eğitiminde farklı yaş gruplarıyla ve farklı çıktı değişkenlerle (bilişsel, duyuşsal vb.) test edilmesi, bundan sonra yapılacak çalışmalarda öğrencilerin hangi beden eğitimi ders ortamlarından ne çıktılar elde ettiklerinin öğrenilmesini sağlayacaktır. Beden eğitimi derslerinde içsel motivasyon ile yaşam boyu fiziksel aktivite alışkanlığı arasında pozitif ilişki olduğu (Hagger, Chatzisarantis, Culverhouse ve Biddle, 2003) bilindiğinden dolayı sağlıklı toplumlar yetiştirme konusunda oldukça önemli bilgiler elde edilebilir. Bununla birlikte öğretmen tarafindan sağlanan özerklik desteğinin sistematik bir gözlem aracı ile ölçülmesi yerine öğrencilerin algıları üzerinden öz-bildirim tarzı bir ölçekle ölçülmesi sonuçların güvenirliği açısından bir sınırlılık oluşturmuştur. Beden eğitimi ders ortamına özgü öğretmenin yarattığı özerklik desteğini ölçen sistematik bir gözlem aracının geliştirilmesi bu sınırlılığın aşılmasını sağlayacaktır. Örneğin De Meyer ve diğerleri (2014) 56 öğretmeni, ortaokul beden eğitimi derslerinde video kamera ile kaydetmiş, tarafsız gözlemcilere, derste ne kadar özerklik desteği sağladığına yönelik bir gözlem aracına göre gözlem yaptırmış, aynı zamanda da öğrencilerin algıladıkları öğretmen kaynaklı özerklik desteğini ölçek aracılığı ile ölçerek sonuçları karşılaştırmışlardır. Öğretmenlerin derste sağladığı özerklik desteğinin gözlem yoluyla ölçülmesi ve öğrencilerin algıladıkları özerklik desteği 
arasında fark olduğunu, öğrencilerin denetleyici öğretmen davranışlarını, gerçeğinden daha yüksek düzeyde algıladıklarını belirlemişlerdir.

Sınırlılıklarına rağmen bu araştırmadan elde edilen bulgulara göre öğrencilerin özerkliğinin desteklendiği beden eğitimi derslerinde hem üç temel psikolojik ihtiyacı tatmin olmuş, hem derse ilişkin içsel olarak motive olmuşlar, hem de zindelik ve konsantrasyonları artarken, olumsuz değerlendirilme korkuları ve sosyal görünüş kaygıları azalmıştır. Bu bulgular doğrultusunda öğretmenlere beden eğitimi derslerinde özerkliği destekleyici, yani öğrencilere seçim hakkı tanıyıcı, onların görüş ve önerilerine değer verici, ders dışında da birey olarak önemsendiklerini hissettirici biçimde davranmaları önerilmektedir. Ayrıca öğretmenlerin beden eğitimi derslerindeki öğrenme ortamına özgü özerklik desteği sağlayıc1 stratejilerin geliştirilmesine yönelik araştırmalar yapılması önerilmektedir.

\section{Kaynaklar}

Adie, J. W., Duda, J. L. \& Ntoumanis, N. (2008). Autonomy support, basic need satisfaction and the optimal functioning of adult male and female sport participants: A test of basic needs theory. Motivation and Emotion, 32, 189-199.

Adie, J. W., Duda, J. L, \& Ntoumanis, N. (2012). Perceived coach-autonomy support, basic need satisfaction and the well- and ill-being of elite youth soccer players: A longitudinal investigation. Psychology of Sport and Exercise, 13, 51-59.

Aelterman, N., Vansteenkiste, M., Van Keer, H., Van den Berghe, L., De Meyer, J. \& Haerens, L. (2012). Students' objectively measured physical activity levels and engagement as a function of betweenclass and between-student differences in motivation toward physical education. Journal of Sport \& Exercise Psychology, 34, 457-480.

Bacanlı, H. ve Çankaya-Cihangir, Z. (2003). Ihtiyaç doyum ölçeği uyarlama çalışması. VII. Ulusal Psikolojik Danışma ve Rehberlik Kongresine sunulmuş bildiri.

Bagøien, T. E., Halvari, H. \& Nesheim, H. (2010). Self-determined motivation in physical education and its links to motivation for leisure-time physical activity, physical activity, and well-being in general. Perceptual and Motor Skills, 111(2), 407-432.

Bartholomew, K. J., Ntoumanis, N., Ryan, R. M. Bosch, J. A. \& Thøgersen-Ntoumani, C. (2011). Self determination theory and diminished functioning: The role of interpersonal control and psychological need thwarting. Personality and Social Psychology Bulletin, 37(11), 1459-1473.

Bartholomew, K. J., Ntoumanis, N., Ryan, R. M. \& Thøgersen-Ntoumani, C. (2011). Psychological need thwarting in the sport context: assessing the darker side of athletic experience. Journal of Sport \& Exercise Psychology, 33, 75-102.

Brunet, J. \& Sabiston, C. M. (2009). Social physique anxiety and physical activity: A self-determination theory perspective. Psychology of Sport and Exercise, 10(3), 329-335.

Cole, D. \& Maxwell, S. E. (1985). Multitrait-multimethod comparisons across populations: A confirmatory factor analysis approach. Multivariate Behavioral Research, 18, 147-167.

Cox, A. E., Duncheon, N. \& Mcdavid, L. (2009). Peers and teachers as sources of relatedness perceptions, motivation and affective responses in physical education. Research Quarterly for Exercise and Sport, 80, 765-773.

Cox, A. E., Ullrich-French, S., Madonia, J. \& Witty, K. (2011). Social physique anxiety in physical education: Social contextual factors and links to motivation and behavior. Psychology of Sport and Exercise, 12(5), 555-562.

Cox, A. E., Ullrich-French, S. \& Sabiston, C.M. (2013). Using motivation regulations in a personcentered approach to examine the link between social physique anxiety in physical education and physical activity-related outcomes in adolescents. Psychology of Sport and Exercise, 14, 461-467. 
De Meyer, J., Tallir, I.B., Soenens, B., Vansteenkiste, M., Aelterman, N. \& Van den Berghe, L. (2013). Does observed controlling teaching behavior relate to students' motivation in physical education? Journal of Educational Psychology, 106(2), 541-554.

Deci, E. L., \& Ryan, R. (1991). A motivational approach to self: Integration in personality. In R. A. Dienstbier (Ed.), Nebraska symposium on motivation, 1990: Perspectives on motivation (pp. 237288). Lincoln, NE, US: University of Nebraska Press.

Deci, E. L. \& Ryan, R. M. (2000). The "what"' and "why" of goal pursuits: human needs and the selfdetermination of behavior. Psychological Inquiry, 11, 227-268.

Deci, E. L. \& Ryan, R. M. (2008). Facilitating optimal motivation and psychological well- being across life's domains. Canadian Psychology, 49(1), 14-23.

Deci, E. L., Ryan, R. M., Gagne, M., Leone, D., Usunov, J. \& Kornazheva, B. P. (2001). Need satisfaction, motivation, and well-being in the work organizations of a former eastern bloc country. Personality and Social Psychology Bulletin, 27, 930-942.

Guay, F., Vallerand, R.J. \& Blanchard, C. (2000). On the assessment of state intrinsic and extrinsic motivation: the situational motivation scale (SIMS). Motivation and Emotion, 24, 175-213.

Haerens, L., Kirk, D., Cardon, G., De Bourdeaudhuij, I. \& Vansteenkiste, M. (2010). Motivational profiles for secondary school physical education and its relationship to the adoption of a physically active lifestyle among university students. European Physical Education Review, 16, 117-139.

Hagger, M. S., Chatzisarantis, N. L., Culverhouse, T. \& Biddle, S. J. (2003). The processes by which perceived autonomy support in physical education promotes leisure-time physical activity intentions and behavior: a trans-contextual model. Journal of Educational Psychology, 95(4), 784.

Hart, E. A., Leary, M. R. \& Rejeski, W. J. (1989). The measurement of social physique anxiety. Journal of Sport \& Exercise Psychology, 11, 94-104.

Hart, T. A., Flora, D. B., Palyo, S. A., Fresco, D. M., Holle, C. \& Heimberg, R. G. (2008). Development and examination of the social appearance anxiety scale. Assessment, 15(1), 48-59.

Koydemir-Özden, S., \& Demir, A. (2009). The relationship between perceived parental attitudes and shyness among Turkish youth: Fear of negative evaluation and self-esteem as mediators. Current Psychology, 28(3), 169-180.

Leary, M. R. (1983). A brief version of the fear of negative evaluation scale. Personality and Social Psychology Bulletin, 9, 371-376.

Leary, M. R. \& Kowalski, R. M. (1995). Social anxiety. New York: Guilford.

Miquelon, P. \& Vallerand, R. J. (2006). Goal motives, well-being, and physical health: happiness and self-realization as psychological resources under challenge. Motivation and Emotion, 30(4), 259272.

Ntoumanis, N. A. (2001). Self-determination approach to the understanding of motivation in physical education. British Journal of Educational Psychology, 71, 225-242.

Ntoumanis, N. (2005). A prospective study of participation in optional school physical education using a self-determination theory framework. Journal of Educational Psychology, 97(3), 444.

Nunnally, J. C. (1978). Psychometric theory (2nd ed.). New York: McGraw-Hill.

Ommundsen, Y. \& Kvalo, S.E. (2007). Autonomy-mastery supportive or performance focused? different teacher behaviours and pupils' outcomes in physical education. Scandinavian Journal of Educational Research, 51(4), 385-413.

Reinboth, M., Duda, J. L. \& Ntoumanis, N. (2004). Dimensions of coaching behavior, need satisfaction, and the psychological and physical welfare of young athletes. Motivation and Emotion, 8, 297313.

Ryan, R. M. \& Deci. E. L. (2000). Self-determination theory and the facilitation of intrinsic motivation, social development, and well-being. American Psychologist, 55(1), 68-78.

Ryan, R.M. \& Frederick, C. (1997). On energy, personality and health: subjective vitality as a dynamic reflection of well-being. Journal of Personality, 65, 529-565.

Sabiston, C. $\quad$ M., Crocker, P. $\quad$ R. $\quad$ E. \& Munroe-Chandler, K. J. (2005). Examining current-ideal discrepancy scores and exercise motivations as predictors of social physique anxiety in exercising females. Journal of Sport Behavior, 28, 68-85.

Sabiston, C. M., Sedgwick, W. A., Crocker, P. R. E., Kowalski, K. C. \& Mack, D. E. (2007). Social physique anxiety in adolescence: An exploration of influences, coping strategies, and health behaviors. Journal of Adolescent Research, 22(1), 78-101. 
Sheikhi Fini, A. A., Kavousian, J., Beigy, A. \& Emami, M. (2010). Subjective vitality and its anticipating variables on students. Procedia Social and Behavioral Sciences, 5, 150-156.

Sheldon, K. M., Ryan, R.M., Deci, E. L. \& Kasser, T. (2004). The independent effects of goal contents and motives on well-being: it's both what you pursue and why you pursue it. Personality and Social Psychology Bulletin, 30, 475-486.

Standage, M. \& Gillison, F. (2007). Students' motivational responses toward school physical education and their relationship to general self-esteem and health-related quality of life. Psychology of Sport and Exercise, 8, 704-721.

Standage, M., Duda, J. L. \& Ntoumanis, N. (2005). A test of self-determination theory in school physical education. British Journal of Educational Psychology, 75, 411-433.

Standage, M., Duda, J.L. \& Ntoumanis, N. (2003). A model of contextual motivation in physical education: using constructs from self-determination and achievement goal theories to predict physical activity intentions. Journal of Educational Psychology, 95, 97-110.

Stone, D. N., Deci, E. L. \& Ryan, R. M. (2009). Beyond talk: creating autonomous motivation through self-determination theory. Journal of General Management, 34(3), 75-91.

Tabachnick, B. G. \& Fidell, L. S. (2007). Using multivariate statistics. Allyn \& Bacon/Pearson Education.

Taylor, I. M. \& Lonsdale, C. (2010). Cultural differences in the relationships among autonomy support, psychological need satisfaction, subjective vitality, and effort in British and Chinese physical education. Journal of Sport \& Exercise Psychology, 32, 655-673.

Vallerand, R. J. (1997). Towards a hierarchical model of intrinsic and extrinsic motivation. In M. P. Zanna (Ed.), Advances in experimental social psychology (pp. 271-359). New York: Academic Press.

Williams, G. C., Gagne, M., Ryan, R. M. \& Deci, E. L. (2002). Facilitating autonomous motivation for smoking cessation. Health Psychology, 21, 40-50.

Williams, G. C., Grow, V. M., Freedman, Z., Ryan, R. M. \& Deci, E. L. (1996). Motivational predictors of weight loss and weight-loss maintenance. Journal of Personality and Social Psychology, 70, $115-126$.

Yli-Piipari, S., Watt, A., Jaakkola, T., Luukkonen, J. \& Nurmi, J. (2009). Relationships between physical education students' motivational profiles, enjoyment, state anxiety, and self-reported physical activity. Journal of Sports Science and Medicine, 8, 327-336.

Yousefi, B., Hassani, Z. \& Shokri, O. (2009). Reliability and factor validity of the 7-item social physique anxiety scale (SPAS-7) among university students in İran. World Journal of Sport Sciences, 2, 201-2014. 


\section{Extended Abstract}

\section{Introduction}

Self-Determination Theory is a theory examines the conditions that foster versus undermine positive human potential. A sub-theory of Basic Psychological Needs Theory within SelfDetermination Theory identifies three global human needs and proposes that these needs are essential for human well-being. Based on the Self-determination Theory, the integrated model of motivational sequence was tested in this study. This sequence explains environmental factors effect psychological mediators, which in turn effect self-determined motivation and consequences. Consequences are at three levels of generality, namely personality, contextual and the situational levels. Motivational sequence has been tested in different contexts including physical education in a number of studies however Turkish physical education contexts has not been explored yet. In addition, understanding the antecedents of psychological well-being as one of the consequence of motivational sequence in adolescents has important implications for especially physical education teachers. Therefore, the aim of the study was to examine contextual antecedents of psychological well-being in physical education classes.

\section{Methodology}

Data were collected from eight classes in two public high schools. Totally 431 high school students $(51,74 \%$ girls, $48,25 \%$ boys $)$ who participated physical education classes with their regular physical education teacher voluntarily participated to the study. Questionnaire packs were administered to students in regular physical education class. Questionnaire pack consisted of the scales tapping students' perception of teacher's autonomy support, basic psychological needs satisfaction, intrinsic motivation, fear of negative evaluation, social appearance anxiety, subjective vitality and concentration. Confirmatory factor analysis was used to test the construct validity of the scales, Cronbach's alpha was used to test the internal consistency of the scales and sub-scales. Pearson Correlation analysis and descriptive statistics were used to examine the relationships among variables. Path analysis was used to explore the reciprocal relationships among students' perceptions of aforementioned variables.

\section{Findings}

Path analysis showed good fit with the data and the factor structure of the scales. Structural equation modelling also showed good fit with the data and supported a model $(\chi 2 / \mathrm{sd}=1,726$; GFI $=0,981 ;$ AGFI $=0,966 ;$ CFI $=0,982 ;$ RMSEA $=0,041)$ in which autonomy support positively predicted students' psychological need satisfaction, which, in turn positively influenced students' intrinsic motivation. Intrinsic motivation positively predicted concentration and subjective vitality positively, fear of negative evaluation negatively.

\section{Discussion}

In the light of study results, teacher's autonomy support in physical education can be considered as a tool to enhance adolescents' concentration and subjective vitality while it can help to reduced adolescents' fear of negative evaluation and social appearance anxiety. Therefore, physical education teachers are recommended to consider how to include students to decision making process, encourage students' initiative taking, value students' opinions and show 
unconditional regard to foster autonomy supportive learning environment. Supporting students' intrinsic motivation for physical education is important especially in adolescence. Because when students engage in physical education lessons, they show positive attitude and intrinsic motivation for participating physical activity in their leisure time before or after the school. Increased physical activity is essential especially in adolescents for creating healthier communities. Future research is recommended to examine specific strategies for enhancing students' autonomy support in physical education context. 